\title{
IMPORTANCE OF EDUCATIONAL INTERVENTION AND PARENTAL KNOWLEDGE ON ATOPIC DERMATITIS IN CHILDREN
}

\author{
Lena Kotrulja ${ }^{1}$, Tina Milavić ${ }^{2}$ Suzana Ožanić Bulić ${ }^{1}$, Natalija Šitum ${ }^{1}$, Ana Bakija Konsuo ${ }^{3}$,

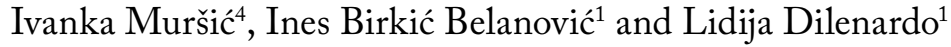

${ }^{1}$ Clinical Department of Dermatovenereology, Sestre milosrdnice University Hospital Center; ${ }^{2}$ Departement of Gastroenterology, Zagreb Children's Hospital, Zagreb; ${ }^{3} \mathrm{Cutis}$ Clinic for Dermatology and Venereology, Dubrovnik; ${ }^{4}$ Clinical Department of Dermatovenereology, Osijek University Hospital Center, Osijek, Croatia

\begin{abstract}
SUMMARY - Atopic dermatitis (AD) is a chronic relapsing, inflammatory skin disease. Failure to treat $\mathrm{AD}$ successfully can often be directly linked to poor treatment adherence as a result of the lack of information about the disease and basic principles of treatment. Several studies have found that making patients active participants in their care through information and education is a successful treatment strategy in AD. The aim of this study was to evaluate parental knowledge on $\mathrm{AD}$ and to stress the importance of therapeutic educational program in long term management and control of the disease. We carried out a short questionnaire-based study among 238 parents of children with AD regarding their knowledge on the etiology and treatment of AD. Our results showed that $21 \%$ of the participants reported corticophobia and were concerned about systemic absorption affecting the child's growth and development even after short application. In children with AD who have food hypersensitivity, $14 \%$ of parents thought that a small amount of food allergen could be beneficial in achieving tolerability. The role of interdisciplinary educational program is to explain the epidemiology and pathogenesis of $\mathrm{AD}$, as well as concomitant atopy related diseases and to teach parents about the importance of appropriate skin care.
\end{abstract}

Key words: Dermatitis, atopic; Parents - education; Patient education as topic; Child; Adrenal cortex hormones - therapeutic use; Phobic disorders - psychology; Treatment refusal - psychology; Treatment failure; Patient compliance

\section{Introduction}

Atopic dermatitis (AD) of childhood is a common inflammatory skin disease affecting $15 \%-20 \%$ of pediatric population under the age of 5 and its prevalence has markedly increased over the past three decades. Its early onset in infancy and chronic relapsing course puts special burden on their families ${ }^{1}$. Children with $\mathrm{AD}$ often have behavioral problems such as increased

Correspondence to: Lena Kotrulja, $M D$, $P h D$, Clinical Department of Dermatovenereology, Sestre milosrdnice University Hospital Center, Vinogradska c. 29, HR-10000 Zagreb, Croatia E-mail: lena.kotrulja@gmail.com

Received September 15, 2014, accepted November 26, 2015 dependency, fearfulness and sleep difficulties². Supporting parents in dealing with the management of $\mathrm{AD}$ presents a challenge for physicians ${ }^{1}$. Educational programs for parents and patients with $\mathrm{AD}$ have been established in the last ten years in different European countries $^{3-6}$.

Standardized interdisciplinary programs involving dermatologists, pediatricians, psychologists and dietitians improve symptoms and clinical manifestations of $\mathrm{AD}$ by optimizing the use of medications resulting in better compliance and leading to a significant increase in the quality of life $(\mathrm{QoL})^{7}$. The role of the interdisciplinary educative program is to explain the epidemiology and pathogenesis of AD and allergy 
related problems (diagnostic, diet, food and respiratory allergy) and to teach parents about appropriate atopic skin care. Atopic skin care includes the use of gentle skin cleaning products, application of adequate amounts of corticosteroid ointment and emollients, resulting in reduced requirement for corticosteroids. Demonstration of the 'wet wrap' technique is an effective method to achieve rapid control of AD and has significantly reduced the need of hospitalization. 'Wet wrapping' involves the application of a weak topical corticosteroid or just emollient under an inner wet and outer dry layer of cotton tubular bandages or garment. Educational approach focusing on topical treatment is a major step in cases where topical treatment is either misunderstood or conducted erroneously due to fear from corticosteroids, therefore having direct implication on compliance ${ }^{8}$.

Topical corticophobia, defined as a non-rational fear from using topical corticosteroids, is very common in $\mathrm{AD}^{9}$. The duration of topical steroid use required to induce perioral dermatitis varies among individuals; only a few weeks of application of even mid-strength or mild topical steroid can result in typical perioral dermatitis, whereas in some patients it develops after years of topical steroid application ${ }^{10}$. Although skin thinning and systemic effects occasionally develop, the concern expressed by people using corticosteroids is out of proportion in relation to the evidence of harm. Educational program offers better information and education of patients regarding the safety, potency and appropriate use of topical corticosteroids ${ }^{11}$.

Avoiding the causal food proteins leads to clinical improvement, but requires a great deal of education because most of the common food allergens (egg, milk, wheat, soya bean and peanut) are ubiquitous in the food supply, and any elimination diet may lead to the risk of nutritional deficits. The role of psychologist is to give information about sleeping problems and behavioral techniques to deal with it, as well as proposing alternative strategies to eliminate the 'vicious circle' of itching and scratching lesions with practical ways of improving the parents' capacity to face the disease related problems ${ }^{12}$.

It is important to underline that the aim of educational program is to improve parents' knowledge on $\mathrm{AD}$, resulting in better understanding of the disease by encouraging active treatment approach of the af- fected individuals and their family members ${ }^{13}$. A recent German study has reported that age related educational programs for the control of $\mathrm{AD}$ in children and adolescents are significantly more effective in the long term management of the disease than conventional treatment approach ${ }^{8}$.

Finally, patient education has been shown to contribute effectively to preventing complications and improving QoL and treatment adherence for numerous chronic illnesses, such as diabetes, asthma, and cardiovascular disease ${ }^{14}$.

\section{Subjects and Method}

The aim of this study was to evaluate parental knowledge about $\mathrm{AD}$ and to stress the importance of the therapeutic educational program in the long term management and control of the disease. We carried out a short questionnaire-based study in 238 parents of children with $\mathrm{AD}$ aged 3 months to 6 years in relation to treatment approach and knowledge on $\mathrm{AD}$, and to assess the prevalence of topical corticosteroid phobia. A short questionnaire comprising 10 questions was administered to parents of children with $\mathrm{AD}$ treated at outpatient dermatology departments in two university hospitals and one private dermatology clinic.

The questionnaire included 10 different questions covering the main different aspects of $\mathrm{AD}$, e.g., the etiology of $\mathrm{AD}$, the influence of heredity on the occurrence of $\mathrm{AD}$, the risk of other atopic disease association, understanding the use of corticosteroids and the problem of corticophobia, the possible different associated symptoms of $\mathrm{AD}$, knowledge about topical immunomodulators, the importance of the elimination diet in $\mathrm{AD}$, understanding different treatment modalities in $\mathrm{AD}$, and the importance of appropriate skin care.

In this paper, four selected question results are presented regarding the knowledge of the parents about topical corticosteroids and immunomodulators, the cause of the disease, and the importance of the elimination diet in AD.

\section{Results}

Topical steroids are currently the mainstay of treatment of $\mathrm{AD}$, but prolonged usage can result in skin atrophy and some other rare side effects. Our results revealed that there was pronounced corticophobia among patients and that a significant proportion of 
parents worried about using topical corticosteroids on their child's skin; $21 \%$ of them were concerned about the risk of skin atrophy after short application and $10 \%$ of parents considered topical corticosteroids to be extremely dangerous and they were worried about systemic absorption affecting the growth and development of their child. On the other hand, only $1 \%$ of respondents thought that corticosteroids could be used without restriction in quantity and length of application, whereas $78 \%$ of parents reported that topical corticosteroids could be administered without side effects if the quantity and duration of treatment was controlled by dermatologists (Fig. 1).

The pathogenesis of AD is unknown, but the disease seems to result from genetic susceptibility, immune dysfunction and epidermal barrier dysfunction. In our study, only $32 \%$ of parents perceived that the basis of $\mathrm{AD}$ etiology lied in pronounced constitutional hypersensitivity to various allergens, $7 \%$ of parents believed that allergy to specific food (most often to egg and cow's milk) was the cause of $\mathrm{AD}$, while $5 \%$ of parents thought that the cause was the child's impaired immunity. The majority of participants thought AD to result from all the above mentioned causes (Fig. 2).

In children with $\mathrm{AD}$ and concomitant food hypersensitivity, $14 \%$ of parents had wrong impression that a
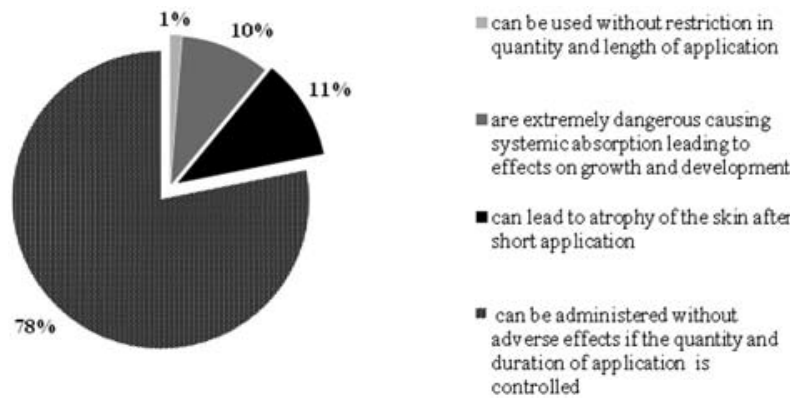

Fig. 1. For topical corticosteroids is true that:
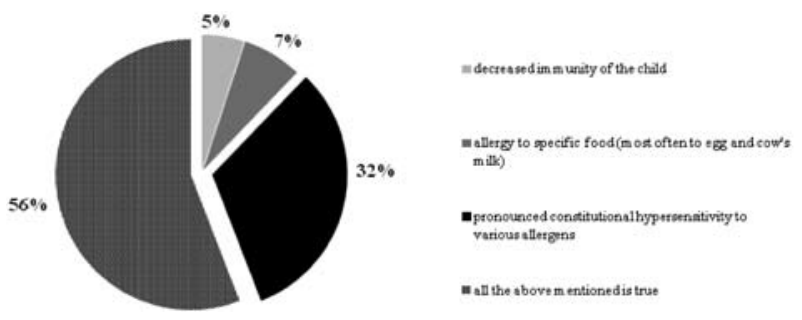

Fig. 2. The cause of atopic dermatitis is: small amount of specific food allergen could be given in order to achieve tolerability, while $1 \%$ thought that it was not necessary for a breastfeeding mother to be on elimination diet. The majority of participants (64\%) thought it was important to completely avoid food to which a child is hypersensitive and that a breastfeeding mother should be on allergen free diet (Fig. 3).

Topical immunomodulators influence the immune system in the skin by altering the action of $\mathrm{T}$ cells that play an important role in eczema and are currently recommended as second-line treatment if eczema has not been controlled adequately with topical steroids, or where there is a risk of side effects from further steroid use. These agents provide effective treatment without causing skin atrophy and other steroid side effects ${ }^{15}$.

In our study, $71 \%$ of parents had no knowledge on topical immunomodulators in the treatment of $\mathrm{AD}$. Our results showed that two percent of parents thought that topical immunomodulators were poorly effective and very expensive, and another $2 \%$ of them worried that these agents could cause skin cancer, while $4 \%$ of parents thought that topical immunomodulators could completely replace topical corticosteroids; $21 \%$ of parents were well informed that topical immunomodulators could be used over a long period without steroid side effects (Fig. 4).
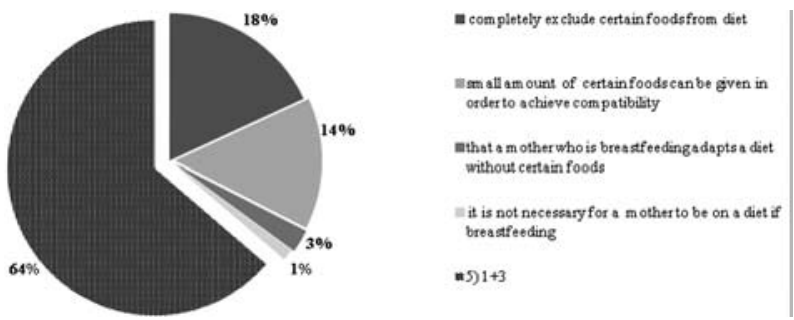

Fig. 3. For children who are hypersensitive to certain food it is important to:
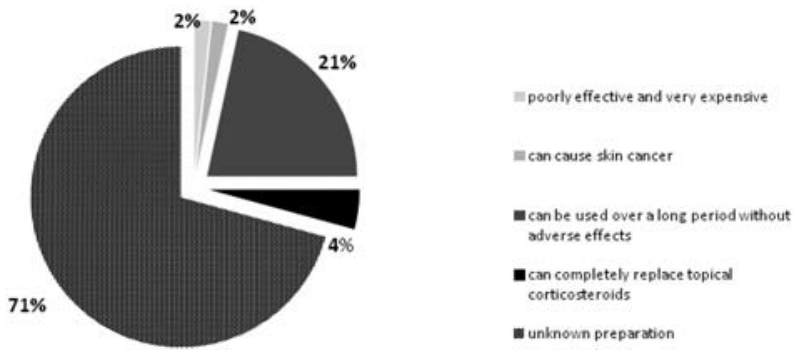

Fig. 4. For topical immunomodulators is true that: 


\section{Discussion}

The study by Staab et al. has clearly shown that educational program for the management of $\mathrm{AD}$ in parents and children greatly improved control of the disease $^{8}$. Poor treatment adherence is the main reason for treatment failure in patients with $\mathrm{AD}$, with the lack of knowledge on $\mathrm{AD}$ and its treatment being the most important cause ${ }^{16}$. A comparative Australian study demonstrated that moderate or severe AD had a more significant impact on families than insulin dependent diabetes mellitus ${ }^{17}$.

Patients with AD and their caregivers have several educational needs that must be met to take control of the disease. They need to understand the chronic and relapsing nature of the disease with no cure at present, but also that it can be managed effectively. They need to be taught how best to apply topical treatment and to be motivated to continue treatment, albeit usually in a modified form when the disease is in remission. Topical treatment of the child with $\mathrm{AD}$ requires active approach of the whole family, while information given to the parents during appointment with the doctor has been found insufficient and further consultations are necessary in order to help, both the child and the family, understand the disease. Topical corticosteroids remain the mainstay of AD therapy, but many therapeutic failures appear to result from poor treatment compliance due to topical corticosteroid phobia, which is common in the management of chronic inflammatory skin diseases, $\mathrm{AD}$ in particular. Sometimes this also leads to patients being exposed to the risks of other potentially more dangerous and, in many cases, unproven treatments. 'Herbal' and 'natural' treatments are often incorrectly assumed to be safe. Some 'herbal' creams actually contain illegal amounts of steroids, sometimes super-potent steroids that should not be used in young children. Patients and especially parents of small children need to be educated about the safety and efficacy of topical corticosteroids and their use ${ }^{18}$.

In the study by Charman et al., 24\% of patients refused the use of topical steroids ${ }^{11}$, and in another study by Aubert-Wastiaux et al., 11 years later, 36\% of patients refused topical steroid application ${ }^{19}$. In our study, 21\% of AD patients felt uncertain about using topical steroid preparations and had little knowledge about their side effects. Therefore, we can conclude that proper education of patients will improve efficacy of treatment and patient compliance. Particular emphasis should be placed on disease management including the use of emollients, controlled use of topical steroids with teaching of 'fingertip unit' and 'wet wrap' bandages.

The main advantage of topical immunomodulators is that they carry no risk of skin thinning at all, and so they can be used on any part of the body including delicate areas such as the face, eyelids, elbows and creases, where they work particularly well. Furthermore, there is no restriction of the length of time the treatments can be used. They are also very effective in maintaining control of $\mathrm{AD}$ once it has been brought under control ${ }^{15}$. Our study showed that there was poor knowledge about topical immunomodulators, as $71 \%$ of parents had never heard about these agents.

Therapeutic patient education in the form of 'Atopic Dermatitis School' improves patient/parentphysician contact, clinical visits are shorter, and there is improved treatment compliance and less concern about using topical steroids ${ }^{3}$. Our approach focuses on practical management of the disease, and information on its etiology, epidemiology, clinical features and complications, particularly infections and exacerbating factors including allergens. Our study highlights the need of providing better information and education of patients and possibly general practitioners regarding the safety, potency and appropriate use of topical corticosteroids.

From December 2011 to September 2014, we organized a structured multidisciplinary educational program at Clinical Department of Dermatovenereoloy, Sestre milosrdnice University Hospital Center. This educational program was offered to the parents of children with AD once a month and covered all important information on the etiology, epidemiology, prevention and treatment of $\mathrm{AD}$, as well as on nutritional and psychological problems important in daily practice. It was carried out by a multiprofessional team consisting of a dermatologist, psychologist and dietitian. The participants were given handouts summarizing the timetable and the most important points of the sessions. The sessions also encouraged participants to share personal experiences and to try out newly learned skills. 


\section{Conclusion}

Lack of information, overstrain, helplessness, and lack of confidence in medical treatment lead to suboptimal management of the disease and increase the use of healthcare resources, including alternative therapies. Patient education has been regarded as having a key role in the self-management of $\mathrm{AD}$. Unlike taking an oral medication, education is essential for the correct use of topical treatment. The aim of educational program is to improve parents' knowledge on $\mathrm{AD}$, resulting in better understanding of the disease by encouraging active treatment approach of the affected individuals and their family members. In order to improve the quality of life of children and families affected by $\mathrm{AD}$, we offered an interdisciplinary, structured educational program which covered medical, nutritional and psychological aspects of the disease. We believe that educational programs of this type, in association with conventional treatment, can be useful in the long term management and control of the disease.

\section{References}

1. Staab D, Von Rueden U, Kehrt R, Erhart M, Wenninger $\mathrm{K}$, Kamtsiuris $\mathrm{P}$, et al. Evaluation of a parental training program for the management of childhood atopic dermatitis. Pediatr Allergy Immunol. 2002;13:84-90. doi: 10.1136/ bmj.332.7547.933.

2. Carroll CL, Balkrishnan R, Feldman SR, Fleischer AB, Manuel JC. The burden of atopic dermatitis: impact on the patient, family and society. Pediatr Dermatol. 2005;22:192-9. doi: 10.1111/j.1525-1470.2005.22303.x.

3. Wenninger K, Kehrt R, Von Rueden U, Lehman C, Binder $\mathrm{C}$, Wahn U, et al. Structured parent education in the management of childhood atopic dermatitis: the Berlin model. Patient Educ Couns. 2000;40:253-61. doi: 10.1016/S07383991(99)00074-9.

4. Grillo M, Gassner L, Marshmann G, Dunn S, Hudson P. Pediatric atopic eczema: the impact of an educational intervention. Pediatr Dermatol. 2006;23(5):428-36. doi: 10.1111/ j.1525-1470.2006.00277.x.

5. Stalder JF, Benier C, Ball A, De Raeve L, Gieler U, Deleuran M, et al. Therapeutic patient education in atopic dermatitis: worldwide experience; Pediatr Dermatol. 2013;30(3):329-34. doi: $10.1111 /$ pde.12024.

6. Barbarot S, Bernier C, Deleuran M, De Raeve L, Eichenfiled L, Hachem ME, et al. Therapeutic patient education in children with atopic dermatitis: position paper on objectives and recommendations. Pediatr Dermatol. 2013;30(2):199-206. doi: $10.1111 /$ bjd.12932.

7. Agner T. Compliance among patients with atopic eczema. Acta Derm Venereol. 2005;215:33-5.

8. Staab D, Diepgen TL, Fartash M, Kupfer J, Lob-Corzilius $\mathrm{T}$, Ring J. Age related, structured educational programs for the management of atopic dermatitis in children and adolescents: multicentre, randomised controlled trial. BMJ 2006;332:933-8. doi: 10.1136/bmj.332.7547.933.

9. Chavogny JM, Adiceom F, Bernier C, Debons M, Stalder JF. Ecole de l'atopie, évaluation d'une expérience d'éducation thérapeutique chez 40 malades. Ann Dermatol Venereol. 2002;129:1003-7. (in French)

10. Bukvić Mokos Z, Kummer A, Lazić Mosler E, Čeović R, Basta-Juzbašić A. Perioral dermatitis: still a therapeutic challenge. Acta Clin Croat. 2015;54:179-85.

11. Charman CR, Moris AD, Williams HC. Topical corticosteroid phobia in patients with atopic eczema. Br J Dermatol. 2000;142(5):931-6.doi:10.1046/j.1365-2133.2000.03473.x.

12. Ricci G, Bendandi B, Aiazzi R, Patrizi A, Masi M. Three years of Italian experience of an educational program for parents of young children affected by atopic dermatitis: improving knowledge produces lower anxiety levels in parents of children with atopic dermatitis. Pediatr Dermatol. 2009;26:1-5. doi: 10.1111/j.1525-1470.2008.00813.x.

13. Ricci G, Bendandi B, Aiazzi R, Patrizi A, Masi M. Educational and medical programme for young children affected by atopic dermatitis and for their parents. Dermatol Psychosom. 2004;5:187-92.

14. Guevara JP, Wolf FM, Grum CM, Clark NM. Effects of educational interventions for self-management of asthma in children and adolescents: systematic review and meta-analysis. BMJ 2003;326:1308-9. doi:10.1136/bmj.326.7402.1308.

15. Flohr C, Williams HC. Evidence based management of atopic eczema. Arch Dis Child Educ Pract Ed. 2004;89:35-9. doi:10.1136/adc.2004.050237.

16. Beattie PE, Lewis-Jones MS. Parental knowledge of topical therapies in the treatment of childhood atopic dermatitis. Clin Exp Dermatol. 2003;28:549-3. doi:10.1046/j.1365-2230 .2003.01357.x.

17. Su J, Kemp A, Varigos G, Nolan T. Atopic eczema: its impact on the family and financial cost. Arch Dis Child. 1997;11:5962. doi: 10.1136/adc.76.2.159.

18. Ramsay HM, Goddard W, Gill S, Moss C. Herbal creams used for atopic eczema in Birmingham, UK illegally contain potent corticosteroids. Arch Dis Child. 2003;88:1056-7. doi:10.1136/adc.88.12.1056.

19. Aubert-Wastiaux H, Moret L, Le Rhun A, Fontenoy AM, Nguyen JM, Leux C, et al. Topical corticosteroid phobia in atopic dermatitis: a study of its nature, origins and frequency. Br J Dermatol. 2011;165(4):808-14. doi: 10.1111/j.1365-2133. 2011.10449.x. 
Sažetak

\section{VAŽNOST EDUKACIJSKE INTERVENCIJE I ZNANJA RODITELJA O ATOPIJSKOM DERMATITISU KOD DJECE}

\section{Kotrulja, T. Milavić, S. Ožanić Bulić, N. Šitum, A. Bakija Konsuo, I. Muršić, I. Birkić Belanović i L. Dilenardo}

Atopijski dermatitis (AD) je kronična, recidivirajuća upalna bolest kože. Neuspjeh u liječenju AD može biti izravno povezan s neprimjerenim pridržavanjem uputa o provođenju terapije kao posljedica nedostatka informacija o bolesti i osnovnim načelima liječenja. Nekoliko studija je utvrdilo da se uspješna strategija u liječenju AD zasniva na aktivnom uključenju bolesnika u provođenje skrbi kroz informiranje i edukaciju o bolesti. Cilj ovoga istraživanja bio je procijeniti poznavanje problematike AD kod roditelja oboljele djece i naglasiti važnost terapijskog edukacijskog programa u uspješnom liječenju i kontroli bolesti. Proveli smo studiju primjenom kratkog upitnika među 238 roditelja djece s AD i mogućnostima liječenja AD. Naši rezultati su pokazali da $21 \%$ sudionika ima izraženu kortikofobiju i strah od sistemske apsorpcije koja može utjecati na rast i razvoj djeteta čak i nakon kratkotrajne primjene kortikosteroida. Kod djece s AD koja imaju dokazanu preosjetljivost na hranu $14 \%$ roditelja mislilo je da mala količina alergena u hrani može biti korisna u postizanju podnošljivosti. Uloga interdisciplinarnog obrazovnog programa je objasniti epidemiologiju i patogenezu AD, kao i popratnu problematiku atopijskih bolesti i poučavati roditelje o njezi atopijske kože.

Ključne riječi: Dermatitis, atopijski; Roditelji-edukacija; Bolesnik, edukacija (kao tema); Kortikosteroidi-terapijska primjena; Fobični poremećaji-psihologija; Dijete; Liječenje, odbijanje-psihologija; Liječenje, neuspješno; Bolesnik, suradljivost 